\title{
Highly Fluorescent Group 13 Metal Complexes With Cyclic, Aromatic Hydroxamic Acid Ligands
}

\author{
Michael Seitz, Evan G. Moore, and Kenneth N. Raymond* \\ Department of Chemistry, University of California, Berkeley, CA 94720-1460, USA. \\ E-mail: raymond@ socrates.berkeley.edu
}

\begin{abstract}
The neutral complexes of two ligands based on the 1-oxo-2-hydroxy-isoquinoline (1,2HOIQO) motif with group 13 metals (Al, Ga, In) show bright blue-violet luminescence in organic solvents. The corresponding transition can be attributed to ligand-centered singlet emission, characterized by a small Stokes shifts of only a few nm combined with lifetimes in the range between 13 ns. The fluorescence efficiency is high, with quantum yields of up to $37 \%$ in benzene solution. The crystal structure of one of the indium(III) complexes (trigonal space group R-3, a = b = 13.0384(15) $\mathrm{A}$, $\mathrm{c}=32.870(8) \AA, \quad=\beta=90^{\circ}, \gamma=120^{\circ}, \mathrm{V}=4839.3(14) \AA^{3}, \mathrm{Z}=6$ ) shows a six-coordinate geometry around the indium center which is close to trigonal-prismatic, with a twist angle between the two trigonal faces of $20.7^{\circ}$. Time-dependent density functional theory (TD-DFT) calculations (Al and Ga: B3LYP/6-31G(d)); In: B3LYP/LANL2DZ) of the fac and mer isomers with one of the two ligands indicate that there is no clear preference for either one of the isomeric forms of the metal complexes. In addition, the metal centers do not have a significant influence on the electronic structure, and as a consequence, on the predominant intraligand optical transitions.
\end{abstract}




\section{Introduction}

Metal complexes with elements of group 13 are significant for a number of active areas of chemical and medical research: $\mathrm{Al}(\mathrm{III})$ has been associated with several diseases such as end-stage renal disease, neurodegenerative dysfunctions like Alzheimer's disease, and bone disorders such as osteoporosis. ${ }^{1}$ $\mathrm{Ga}(\mathrm{III})$ and $\mathrm{In}(\mathrm{III})$ are of particular interest because of the availability of the radioisotopes ${ }^{67} \mathrm{Ga},{ }^{68} \mathrm{Ga}$,

${ }^{111}$ In, and ${ }^{113}$ In which are useful in the area of nuclear medicine (e.g. for positron emission tomography and single photon emission computed tomography). ${ }^{2}$ In addition, gallium(III), in terms of its coordination chemistry, is an excellent diamagnetic analogue of the biologically important (but paramagnetic) $\mathrm{Fe}(\mathrm{III})$ ion and as such enables NMR investigations for structure elucidation purposes. ${ }^{3}$ Luminescence from complexes of group 13 metals has also been exploited for a number of applications, for example in the aluminium ${ }^{4}$ and gallium ${ }^{5}$ complexes of 8-hydroxyquinoline and other chromophores ${ }^{6}$ as organic light emitting diodes (OLED's) and in the classical analysis for aluminium 2-(2,4dihydroxyphenyl)-3,5,7-trihydroxy-chromen-4-one (known by the common name 'morin') as a reagent. $^{7}$

We recently introduced the ligand $\mathrm{H}_{3} 2$ (Figure 1) with a new chelating unit based on 1-oxo-2hydroxy-isoquinolinone-3-carboxylic acid (1,2-HOIQO) ${ }^{8}$ Ligands of this type have been found to be very efficient for the complexation of hard metal ions such as $\mathrm{Be}^{2+}, \mathrm{Fe}^{3+}$, and $\mathrm{Ln}^{3+}$. In an extension of our previous work, we report here the synthesis of the new bidentate 1,2-HOIQO ligand H1 (Figure 1) and the coordination chemistry and the luminescence properties of the complexes of the two ligands with the trivalent group 13 metals $\mathrm{Al}, \mathrm{Ga}$, and In.
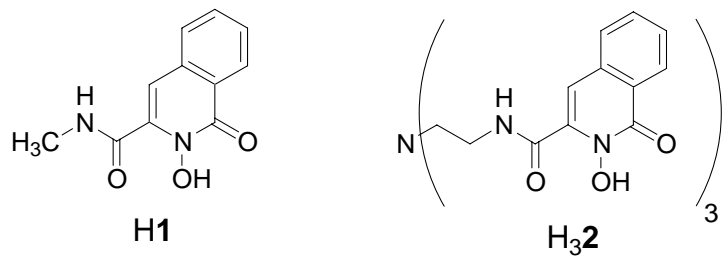

Figure 1. Cyclic, aromatic hydroxamic acid ligands used in this study. 


\section{Results and Discussion}

\subsection{Complex Syntheses}

The synthesis of the metal complexes of $\mathrm{H} 1$ and $\mathrm{H}_{3} 2$ was readily achieved by refluxing either ligand with the appropriate metal salt in methanol using pyridine as base (Scheme 1). This procedure gave the expected mononuclear complexes as colorless solids in analytically pure form after drying under reduced pressure at slightly elevated temperature (see the Experimental Section 4).

Scheme 1. Synthesis of the complexes of $\mathrm{H} 1$ and $\mathrm{H}_{3} 2$ with group 13 metals.

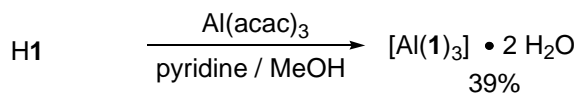

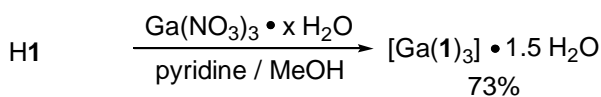

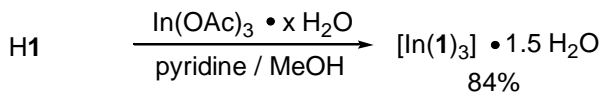

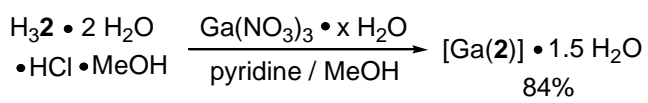

$$
\begin{aligned}
& \begin{array}{llr}
\mathrm{H}_{3} 2 \cdot 2 \mathrm{H}_{2} \mathrm{O} & \operatorname{In}(\mathrm{OAc})_{3} \cdot \times \mathrm{H}_{2} \mathrm{O} & {[\ln (2)]} \\
& \text { pyridine } / \mathrm{MeOH} & 54 \%
\end{array}
\end{aligned}
$$

Unlike the other complexes, the reaction of $\mathrm{H}_{3} 2$ with aluminum salts unexpectedly yielded material that was not consistent with the formation of a monomeric species. Its structure could not be determined and its full characterization awaits further study. The neutral metal complexes shown in Scheme 1 are very sparingly soluble in water and alcoholic media $(\mathrm{MeOH}, \mathrm{EtOH})$, whereas they show good to moderate solubility in most other organic solvents, even in highly non-polar ones such as $n$-hexane.

\subsection{Crystal Structures}

Crystal growing attempts of complexes with H1 were unsuccessful and produced at best only extremely disordered nanocrystals. The observed behavior is likely due to the presence of both $f a c$ and 
mer isomers which cocrystallize because of their very similar overall size and shape (vide infra). This phenomenon resembles the properties of tris(8-hydroxyquinoline) aluminum $\left(\mathrm{Alq}_{3}\right)$, one of the most studied coordination compounds due to its technological importance for OLED production. ${ }^{4}$ In contrast to this, complexes with $\mathrm{H}_{3} 2$ are geometrically restricted to the formation of the fac isomer. Consequently, it was possible to grow single crystals of $[\operatorname{In}(2)]$ through vapor diffusion techniques. This compound, which crystallizes in the trigonal space group R-3, features a racemic pair of $C_{3}$ symmetric complexes with the central tertiary amine nitrogen (N1) and the metal center (In1) on the threefold axis (Table 1, Figures 2 and 3).

Table 1. X-ray crystallographic data collection and refinement details for [ $\operatorname{In}(2)]$ :

\begin{tabular}{|c|c|}
\hline & {$[\operatorname{In}(2)]$} \\
\hline formula & $\mathrm{C}_{36} \mathrm{H}_{30} \mathrm{InN}_{7} \mathrm{O}_{9}$ \\
\hline mol wt. [g mol$\left.{ }^{-1}\right]$ & 819.49 \\
\hline cryst. system & trigonal \\
\hline Space group & R-3 (No. 148) \\
\hline $\mathrm{a}=\mathrm{b}[\AA]$ & 13.0384(15) \\
\hline c [Å] & $32.870(8)$ \\
\hline$\alpha=\beta\left[{ }^{\circ}\right]$ & 90 \\
\hline$\gamma\left[{ }^{\circ}\right]$ & 120 \\
\hline $\mathrm{V}\left[\AA^{3}\right]$ & 4839.3(14) \\
\hline $\mathrm{Z}$ & 6 \\
\hline$\rho_{\text {diff }}\left[\mathrm{g} \mathrm{cm}^{-3}\right]$ & 1.687 \\
\hline radiation $[\AA ̊]$ & Mo-K $\alpha(0.71073)$ \\
\hline$\mu\left[\mathrm{mm}^{-1}\right]$ & 0.805 \\
\hline temp. $[\mathrm{K}]$ & $169(2)$ \\
\hline $\max \left[{ }^{\circ}\right]$ & 26.40 \\
\hline Meas. refls. & 7861 \\
\hline Indep. refls. & 2116 \\
\hline refls. in ref. & $1636(\mathrm{I}>2 \sigma(\mathrm{I}))$ \\
\hline parameters & 160 \\
\hline$R^{[\mathrm{a}]}$ & 0.0344 \\
\hline$w R^{[\mathrm{b}]}$ & 0.0706 \\
\hline$R^{[\mathrm{a]}]}$ (all data) & 0.0560 \\
\hline$w R$ (all data) & 0.0761 \\
\hline goodness of fit & 1.012 \\
\hline
\end{tabular}




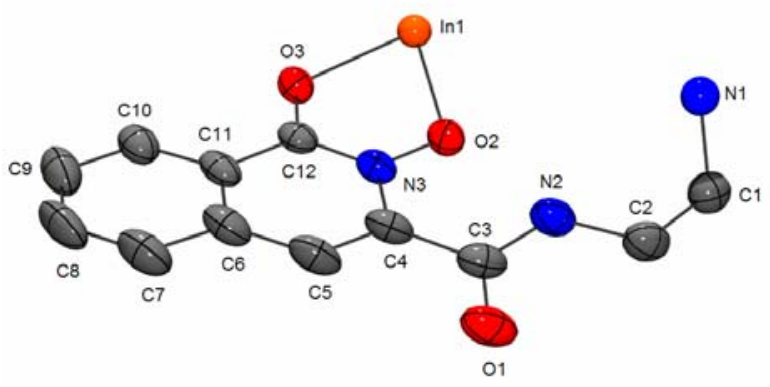

Figure 2. Asymmetric unit of $[\operatorname{In}(\mathbf{2})]$. Thermal ellipsoid plot (ORTEP-3 for Windows, ${ }^{9} 50 \%$ probability level) with atom numbering scheme. Hydrogens omitted. Selected bond lengths $[\AA]$, angles $\left[{ }^{\circ}\right]$ and dihedral angles $\left[^{\circ}\right]:$ In1-O2 = 2.139, In1-O3 = 2.141, O2-In1-O3 = 74.58, O2-In1-O3' = 116.69, O2In1-O3' ${ }^{\prime}=147.93$, O2-In1-O2' = 84.71, O3-In1-O3' = 92.95, O2-N1-In1-O3 = 20.67.
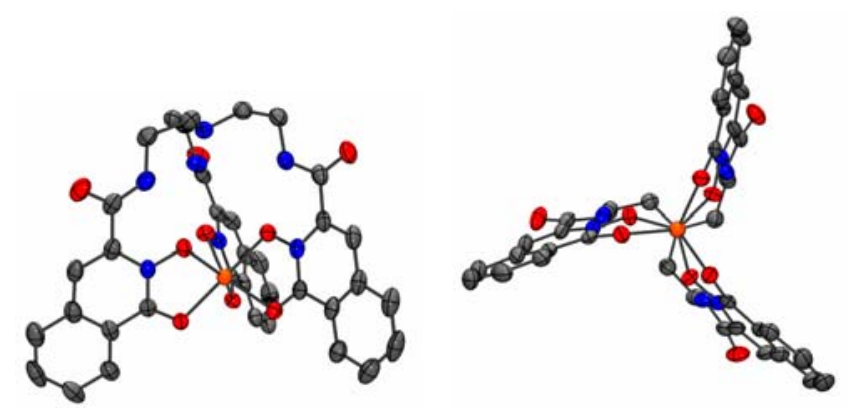

Figure 3. Side-view (left) and view down the $C_{3}$ axis (right) of $[\operatorname{In}(\mathbf{2})]$. Thermal ellipsoid plot (ORTEP3 for Windows, ${ }^{9} 50 \%$ probability level). Hydrogens omitted.

The geometry around the six-coordinate indium cation can be best described by the twist angle $\alpha$ (Figure 4) between the two triangular faces, that are formed by the two sets of symmetry-equivalent oxygen atoms (Figure 2: $\mathrm{O} 2$ and $\mathrm{O} 3$ ). The value of $\alpha=20.7^{\circ}$ in $[\operatorname{In}(2)]$ is more characteristic for a trigonal-prismatic arrangement (ideal: $\alpha=0^{\circ}$ ) than it is for the more common octahedron (ideal: $\alpha=$ $\left.60^{\circ}\right)$. The observed distortion towards this rather rare six-coordinate geometry is not unusual for indium(III) complexes and has been seen in similar compounds. ${ }^{10}$ 


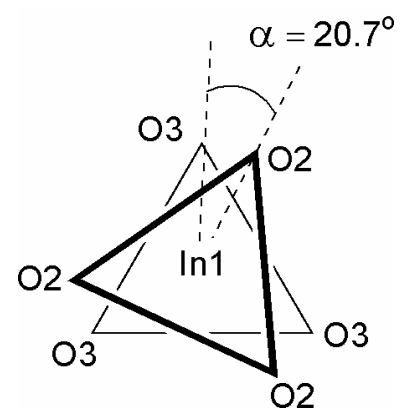

Figure 4. View down the $C_{3}$ axis (N1-In1) - Twist angle $\alpha$ between triangular faces.

\subsection{NMR Spectroscopy}

In order to obtain more structural information on the tris(bidentate) $\left[\mathrm{M}(\mathbf{1})_{3}\right]$ species and the distribution of the two possible geometric isomers (fac vs. mer), ${ }^{11}$ their ${ }^{1} \mathrm{H}$ NMR spectra were analyzed (Figure 5).

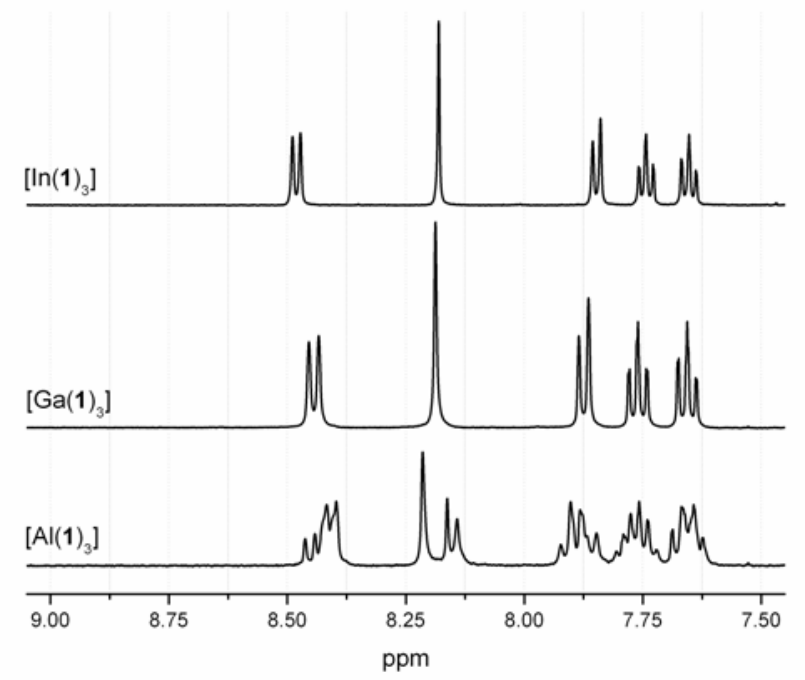

Figure 5. Aromatic region of the ${ }^{1} \mathrm{H}$ NMR (400 $\mathrm{MHz}, \mathrm{CDCl}_{3}, 293 \mathrm{~K}$ ) spectra of the metal complexes with H1.

The spectra show that for the aluminum complex $\left[\mathrm{Al}(\mathbf{1})_{3}\right]$ the dominant species is the $C_{1}$ symmetric mer isomer with three sets of signals for the three bound ligands, whereas both the gallium and indium complexes exhibit only one set of signals. This is most likely due to rapidly (on the NMR time scale) interconverting geometric isomers ( $f a c$ and mer), as observed in a number of similar examples. ${ }^{12}$ To further investigate this issue we performed variable-temperature ${ }^{1} \mathrm{H}$ NMR with $\left[\operatorname{In}(\mathbf{1})_{3}\right]$ (Figure 6). 


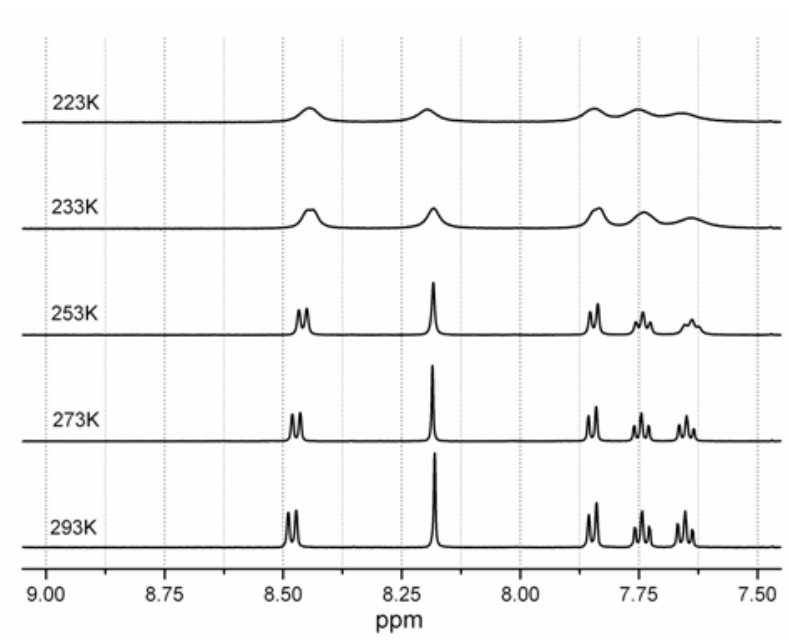

Figure 6. Aromatic region of the variable-temperature ${ }^{1} \mathrm{H}$ NMR $\left(500 \mathrm{MHz}, \mathrm{CDCl}_{3}\right) \operatorname{spectra}$ of $\left[\operatorname{In}(\mathbf{1})_{3}\right]$.

Going from room temperature ( $293 \mathrm{~K}$ ) with relatively sharp signals to $223 \mathrm{~K}$ results in the broadening of the peaks which is mainly due to an increase in the viscosity of the solvent $\left(\mathrm{CDCl}_{3}\right)$ near its freezing point. Without the appearance of new sets of signals it remains unclear whether $\left[\operatorname{In}(\mathbf{1})_{3}\right]$ in solution exists exclusively as the symmetric fac isomer or whether it actually is a mixture of $m e r$ and fac with a very low energetic barrier for the interconversion process that cannot be inhibited even at low temperature (223 K). DFT calculations, however, suggest the latter explanation (vide infra).

As expected, the ${ }^{1} \mathrm{H}$ NMR spectra of the mononuclear $[\mathrm{M}(2)]$ species $(\mathrm{M}=\mathrm{Ga}, \mathrm{In})$ in $\mathrm{CDCl}_{3}$ show only one single set of signals possible for the three ligand arms, consistent with the presence of only the $C_{3}$ symmetric $f a c$ isomer as observed for $[\operatorname{In}(2)]$ in the solid state (vide supra).

\subsection{Photophysical Properties}

The ligands $\mathrm{H} 1$ and $\mathrm{H}_{3} 2$ are essentially non-fluorescent in solution. In contrast to this, group 13 metal complexes with these ligands are highly luminescent upon UV irradiation. This phenomenon is known in the literature as "chelation-enhanced fluorescence (CHEF)" and is in most cases due to the suppression of low-lying charge-transfer transitions upon metal binding. ${ }^{13}$ A preliminary solvent screening revealed that the emission efficiency for all complexes was generally high in relatively unpolar solvents (such as $\mathrm{CHCl}_{3}$, toluene, THF, etc.) and decreased in more polar media such as DMF and $\mathrm{CH}_{3} \mathrm{CN}$. The best solvent in this respect was benzene and subsequent measurements were carried 
out in this solvent. The UV-vis absorption spectra and the fluorescence spectra $\left(\lambda_{\mathrm{ex}}=327 \mathrm{~nm}\right)$ for all five complexes are very similar. Table 2 summarizes the properties of these species and Figure 7 shows as a representative example the spectra for $\left[\mathrm{Al}(\mathbf{1})_{3}\right]{ }^{14}$

Table 2. Photophysical properties of group 13 metal complexes with $\mathrm{H} 1$ and $\mathrm{H}_{3} 2$ in benzene solution.

\begin{tabular}{|c|c|c|c|c|c|c|}
\hline Complex & $\begin{array}{c}\text { Abs.: } \lambda_{\max } \\
{[\mathrm{nm}]}\end{array}$ & $\begin{array}{c}\lambda_{\mathrm{exc}} \\
{[\mathrm{nm}]}\end{array}$ & $\begin{array}{c}\mathrm{Em} .: \lambda_{\max } \\
{[\mathrm{nm}]}\end{array}$ & $\Phi[\%]$ & $\tau[\mathrm{ns}]$ & $\chi^{2}$ \\
\hline$\left[\mathrm{Al}(\mathbf{1})_{3}\right] \bullet 2 \mathrm{H}_{2} \mathrm{O}$ & $\begin{array}{l}321 \\
335 \\
350\end{array}$ & 327 & $\begin{array}{l}357 \\
373 \\
391\end{array}$ & 37.4 & $\begin{array}{l}3.4(87 \%) \\
2.6(13 \%)\end{array}$ & 1.22 \\
\hline$\left[\mathrm{Ga}(\mathbf{1})_{3}\right] \bullet 1.5 \mathrm{H}_{2} \mathrm{O}$ & $\begin{array}{l}320 \\
334 \\
350 \\
\end{array}$ & 327 & $\begin{array}{l}358 \\
374 \\
391 \\
\end{array}$ & 23.7 & $\begin{array}{l}2.4(62 \%) \\
1.9(38 \%)\end{array}$ & 1.24 \\
\hline$\left[\operatorname{In}(\mathbf{1})_{3}\right] \bullet 1.5 \mathrm{H}_{2} \mathrm{O}$ & $\begin{array}{l}320 \\
334 \\
350\end{array}$ & 327 & $\begin{array}{l}359 \\
374 \\
393 \\
\end{array}$ & 7.2 & $\begin{array}{c}2.4(5 \%) \\
0.51(95 \%)\end{array}$ & 1.26 \\
\hline$[\mathrm{Ga}(\mathbf{2})] \bullet 1.5 \mathrm{H}_{2} \mathrm{O}$ & $\begin{array}{l}321 \\
334 \\
351 \\
\end{array}$ & 327 & $\begin{array}{l}361 \\
376\end{array}$ & 25.5 & 2.8 & 0.90 \\
\hline$[\operatorname{In}(2)]$ & $\begin{array}{l}322 \\
337 \\
352 \\
\end{array}$ & 327 & $\begin{array}{l}358 \\
378\end{array}$ & 13.0 & 1.6 & 1.06 \\
\hline
\end{tabular}

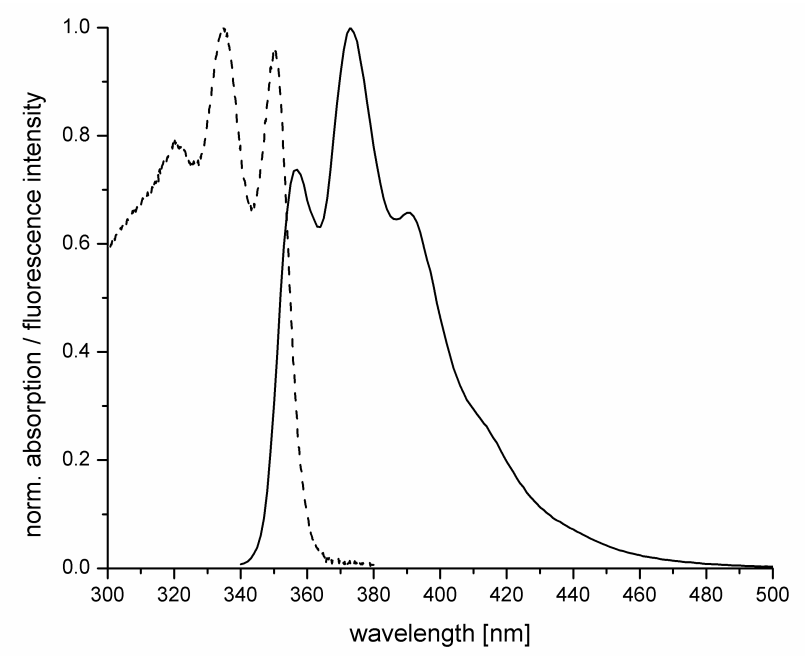

Figure 7. Normalized UV-visible (dashed line) and fluorescence (solid line) spectra for $\left[\mathrm{Al}(\mathbf{1})_{3}\right] \bullet 2$ $\mathrm{H}_{2} \mathrm{O}$ in benzene solution.

The absorption spectra show a strong band around $335 \mathrm{~nm}$ featuring a pronounced structure with a separation of ca. $1330 \mathrm{~cm}^{-1}$ for this vibronic progression. The latter phenomenon, which is also observed for a number of aromatic hydrocarbons (eg. benzene, naphthalene, and anthracene), is mirrored in the fluorescence spectra, which show a Stokes shift of only a few nm and maxima around 
$375 \mathrm{~nm}$ (blue-violet). Together with the observation of short lifetimes $(\tau \approx 0.5-3.4 \mathrm{~ns}$, Table 2 : second last column), this indicates a solely ligand-centered singlet parentage for this transition. For the complexes with $\mathrm{H}_{3} 2$, which can only generate one isomeric form, a clear monoexponential behavior is observed for the luminescence lifetimes. By contrast, the time resolved fluorescence decays for the $\left[\mathrm{M}(\mathbf{1})_{3}\right]$ species $(\mathrm{M}=\mathrm{Al}, \mathrm{Ga}, \mathrm{In})$ were best modeled by biexponential decay functions, yielding two independent lifetimes. We take this behavior to indicate the presence of both fac and mer forms of the complexes in solution, and tentatively ascribe the longer lived component to the $f a c$ isomer by comparison to the obtained values for the mononuclear $[\mathrm{M}(2)]$ species.

Quantum yield measurements gave values between $7-37 \%$ in benzene, which compare well with previously reported, successful systems for luminescent metal complexes of group 13 metals (Al, Ga, In) in solution. ${ }^{15}$ As a general trend, the quantum yields decrease with the size of the group 13 metal (e.g. in $\left.\left[\mathrm{M}(\mathbf{1})_{3}\right]: \mathrm{Al}=37.4 \%, \mathrm{Ga}=23.7 \%, \mathrm{In}=7.2 \%\right)$. The rigidification of the complex structure through the tripodal design of $\mathrm{H}_{3} 2$ can diminish the likelihood of non-radiative de-excitation processes and improves the emission efficiencies (e.g. $\left[\operatorname{In}(\mathbf{1})_{3}\right]=7.2 \%$ vs. $\left.[\operatorname{In}(\mathbf{2})]=13.0 \%\right)$. The same trend has also been seen in other ligand systems. ${ }^{15 a}$

\subsection{Density Functional Theory Calculations}

In order to investigate the electronic structure of our metal complexes from a theoretical standpoint, we performed density functional theory (DFT) calculations on our system. The main goal was to see which influence the hydroxamic acid binding unit has on the fac/mer isomer distribution in complexes with $\mathrm{H1}$ and to get insights into the trends of the basic electronic structure with the variation of the central group 13 metal (Al, Ga, In). Geometry optimization of the fac and mer isomers of the complexes with the metals $\mathrm{Al}$ and $\mathrm{Ga}$ was performed within the Gaussian 03 package ${ }^{16}$ by DFT with the B3LYP exchange correlation functional using the 6-31G(d) basis set. These conditions were used for similar group 13 metal complexes (e.g. Alq ${ }_{3}$ ) before and have proved to be on a sufficient level of theory to describe the properties of the complexes adequately. ${ }^{17}$ For the In complex, the LANL2DZ basis set was 
used instead. $^{18,19}$ Time-dependent DFT (B3LYP / with 6-31G(d) for Al, Ga and LANL2DZ for In) calculations yielded the absorption properties (excitation wavelength, oscillator strengths, etc.) of the metal complexes. The data obtained from these calculations are summarized in Tables 3-5 and Figures 8-9.

Table 3. DFT calculations: Basic parameters for $\left[\mathrm{M}(\mathbf{1})_{3}\right]$.

\begin{tabular}{|c|c|c|c|c|c|c|}
\hline & $f a c-\left[\mathrm{Al}(\mathbf{1})_{3}\right]^{\mathrm{a}}$ & $m e r-\left[\operatorname{Al}(\mathbf{1})_{3}\right]^{\mathrm{a}}$ & $f a c-\left[\mathrm{Ga}(\mathbf{1})_{3}\right]^{\mathrm{a}}$ & $\operatorname{mer}-\left[\mathrm{Ga}(\mathbf{1})_{3}\right]^{\mathrm{a}}$ & $f a c-\left[\operatorname{In}(\mathbf{1})_{3}\right]^{\mathrm{b}}$ & $m e r-\left[\operatorname{In}(\mathbf{1})_{3}\right]^{\mathrm{b}}$ \\
\hline HOMO-LUMO gap [eV] & 4.24 & 4.22 & 4.27 & 4.25 & 4.28 & 4.28 \\
\hline $\begin{array}{l}\text { dipole moment } \\
{[\mathrm{D}]}\end{array}$ & 5.02 & 2.54 & 5.10 & 2.35 & 6.52 & 3.08 \\
\hline $\begin{array}{c}\Delta \mathrm{E}(\text { fac-mer }) \\
{\left[\mathrm{kcal} \mathrm{mol}^{-1}\right]}\end{array}$ & \multicolumn{2}{|c|}{0.029} & \multicolumn{2}{|c|}{-0.327} & \multicolumn{2}{|c|}{0.075} \\
\hline
\end{tabular}

${ }^{\mathrm{a} B}$ B $\mathrm{LYP} / 6-31 \mathrm{G}(\mathrm{d}) ;{ }^{\mathrm{b}} \mathrm{B} 3 \mathrm{LYYP} / \mathrm{LANL} 2 \mathrm{DZ}$

The optimized structures show no unusual features and consist of only slightly distorted octahedrally coordinated metal centers in all cases. ${ }^{19}$ As can be seen from Table 3, the HOMO-LUMO gaps for all six species are almost identical (ca. $4.25 \pm 0.03 \mathrm{eV}$ ), the first indication that the metal center does not play a significant role (vide infa). The dipole moments show the expected trend that the fac isomers have higher values than the mer species. The most interesting parameter is the calculated energy difference between the two isomers: $\operatorname{mer}-\left[\mathrm{M}(\mathbf{1})_{3}\right]$ is only slightly more stable than the fac analogue for $\mathrm{M}=\mathrm{Al}$ and In, whereas this trend is even reversed for the Ga complexes. The obtained values for $|\Delta \mathrm{E}|$ $<0.33 \mathrm{kcal} \mathrm{mol}^{-1}$ are smaller than the available thermal energy $\left(293 \mathrm{~K}: \mathrm{kT} \approx 0.6 \mathrm{kcal} \mathrm{mol}^{-1}\right)$ at room temperature. Therefore, from a purely thermodynamic standpoint, the two isomers could be expected to interconvert very rapidly, even at low temperatures as was suspected in the context of interpreting the ${ }^{1} \mathrm{H}$ NMR experiments (see section 2.3 above). The observation that for the aluminum complex the NMR spectrum shows separate signals for both the fac and mer species, with a predominance of the mer form, is most likely due to less favorable (slower) interconversion kinetics in comparison to the Ga and In complexes, probably a reflection of the stronger Al-O bond compared to Ga-O and In-O. The 
computational prediction of the absence of a clear isomeric preference in our system is surprising, taking into account the clear dominance of the mer species for a variety of related 8-hydroxyquinoline group 13 metal complexes, such as $\mathrm{Alq}^{3}$.

The electronic structure around the HOMO-LUMO gap of the metal complexes is exemplified by the two isomers of $\left[\mathrm{Al}(\mathbf{1})_{3}\right]$ in Figure 8 and for the three mer species of $[\mathrm{M}(\mathbf{1})](\mathrm{M}=\mathrm{Al}, \mathrm{Ga}, \mathrm{In})$ in Figure 9. A few general trends can be seen comparing the two Al complexes in Figure 8. Both show considerable delocalization of the ligand based orbitals over at least two chelants, especially for the occupied orbitals (Figure 8: orbitals $174=$ HOMO-2, $175=$ HOMO-1, $176=$ HOMO). The exceptions are the three virtual orbitals in mer-[Al(1) 3 (Figure 8: orbitals $177=\mathrm{LUMO}, 178=\mathrm{LUMO}+1,179=\mathrm{LUMO}+2$ ) which are each localized on only one of the three non-equivalent 1,2-HOIQO binding units. For the fac isomer, the HOMO-2 and HOMO-1 orbitals (Figure 8) are very close in energy. The same holds true for the LUMO, LUMO+1, and LUMO+2 orbitals (Figure 8). Importantly, the metal centers do not participate in a significant way. The same trends can be seen in the Ga and In complexes. ${ }^{19}$ Figure 9 shows a comparison of the frontier orbitals in the mer isomers of the complexes. The orbitals are almost identical and show no dependence on the nature of the metal center $(\mathrm{M}=\mathrm{Al}, \mathrm{Ga}, \mathrm{In})$.

The results of the time-dependent DFT (TD-DFT) calculations on the complexes are summarized in Tables 4 and 5. 


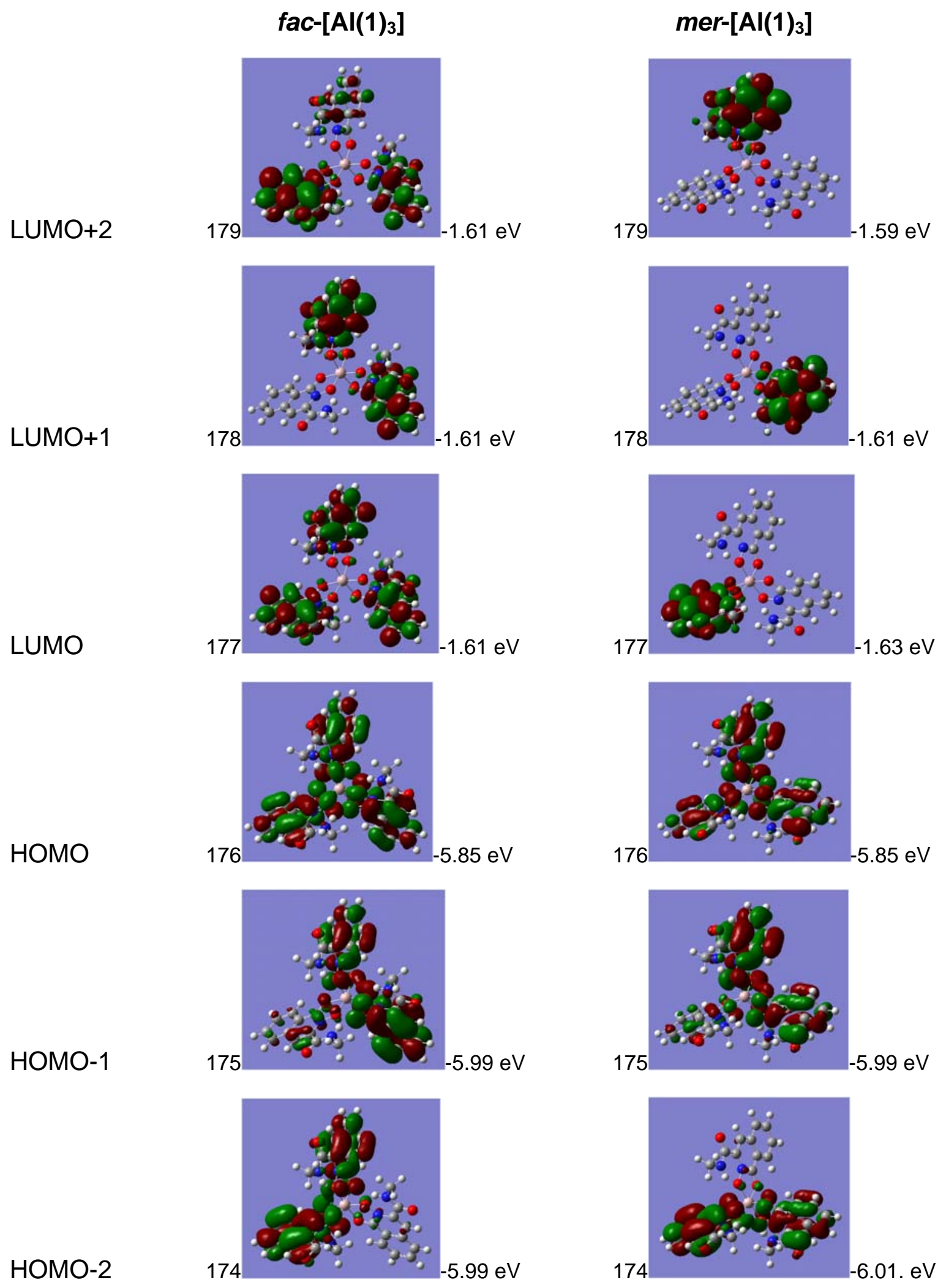

Figure 8. Calculated (B3LYP/6-31G(d)) frontier orbitals for the two isomers of $\left[\mathrm{Al}(\mathbf{1})_{3}\right]$. 


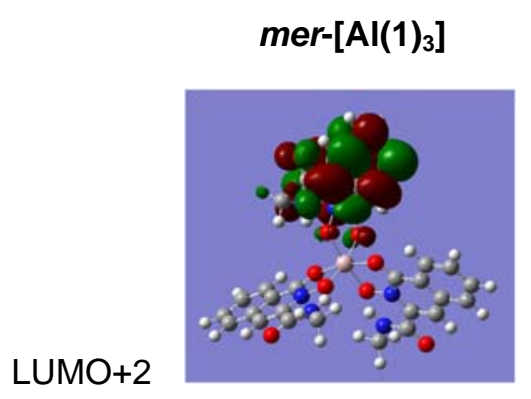

LUMO+1

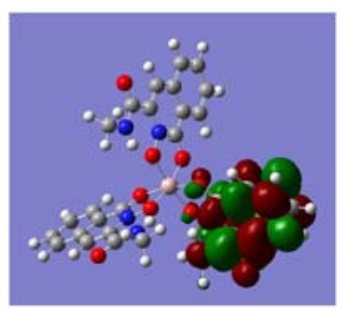

LUMO

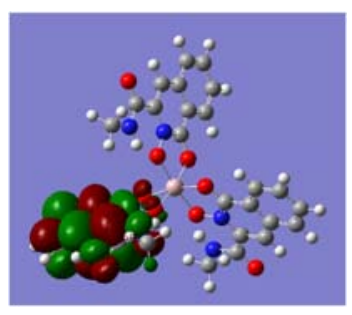

HOMO

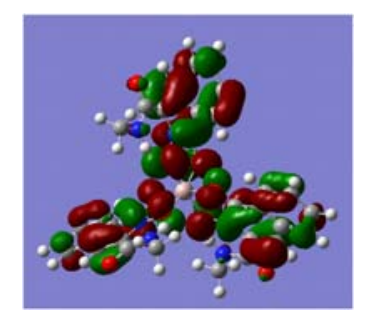

HOMO-1

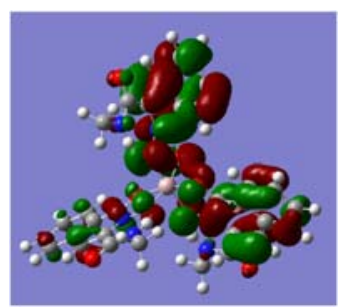

HOMO-2

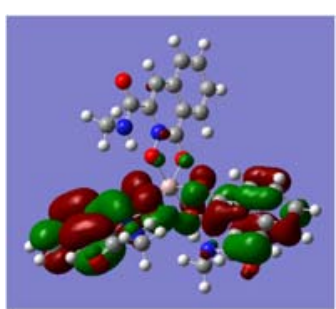

\section{$\operatorname{mer}-\left[\mathrm{Ga}(1)_{3}\right]$}
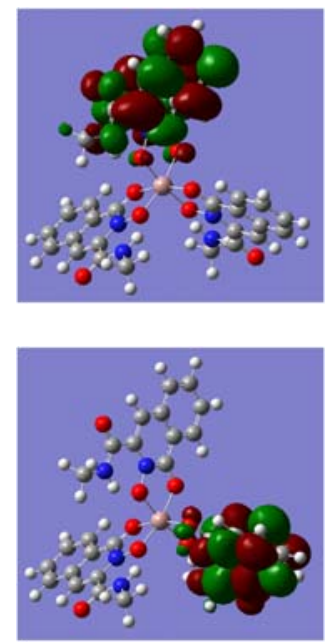

$\operatorname{mer}-\left[\ln (1)_{3}\right]$
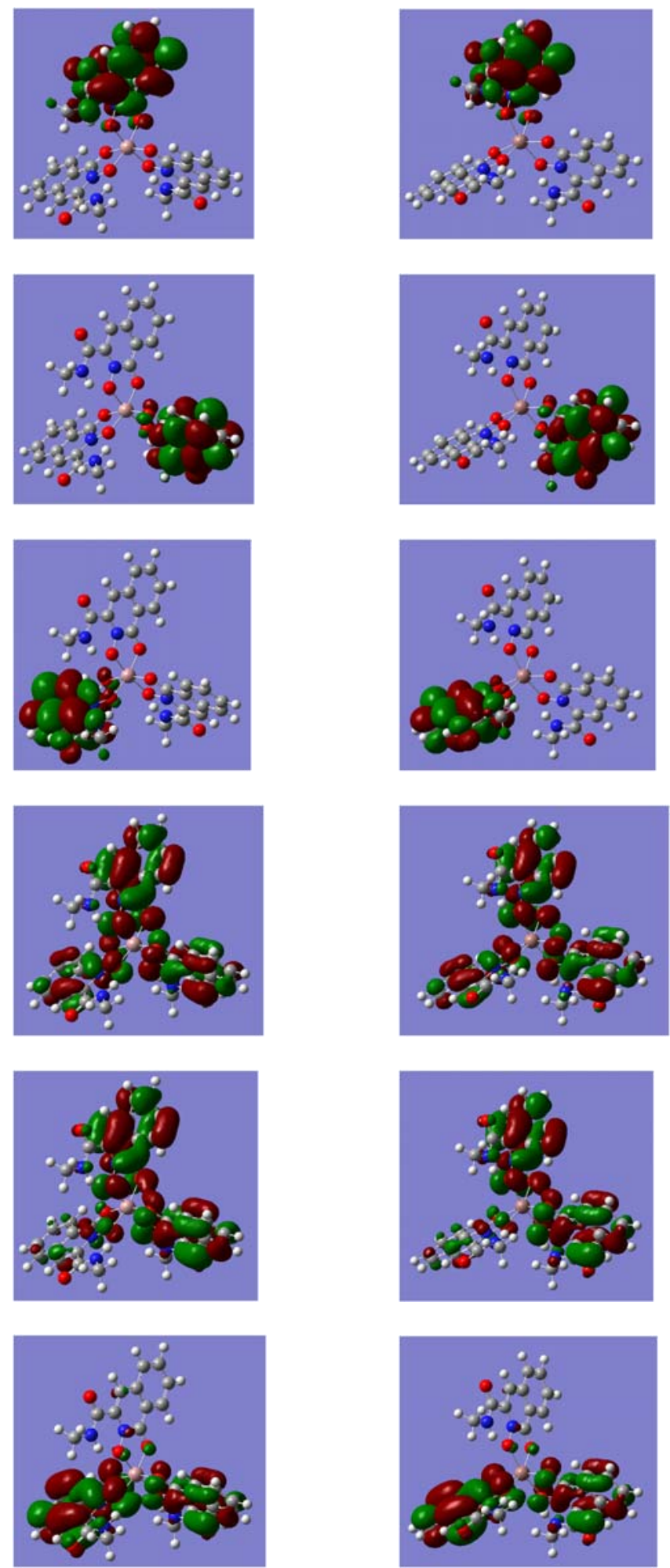

Figure 9. Calculated (B3LYP / with 6-31G(d) for Al, Ga and LANL2DZ for In) frontier orbitals for the mer isomers of $\left[\mathrm{M}(\mathbf{1})_{3}\right](\mathrm{M}=\mathrm{Al}, \mathrm{Ga}, \mathrm{In})$. 
Three long-wave bands are found in each case. For all six metal complexes these absorptions are predominantly composed of transitions involving HOMO $\rightarrow$ LUMO $(\mathrm{Al}: 176 \rightarrow 177$, Ga: $185 \rightarrow 186$, In: $171 \rightarrow 172), \mathrm{HOMO} \rightarrow \mathrm{LUMO}+1(\mathrm{Al}: 176 \rightarrow 178, \mathrm{Ga}: 185 \rightarrow 187$, In: $171 \rightarrow 173)$, and HOMO $\rightarrow$ LUMO+2 $(\mathrm{Al}: 176 \rightarrow 179, \mathrm{Ga}: 185 \rightarrow 188, \mathrm{In}: 171 \rightarrow 174)$. In every case, the strongest transitions are predicted to be the long-wave ones (with oscillator strengths $f \approx 0.10-0.13$ ). While metal-centered orbitals do not participate in the frontier orbitals, there is a slight trend towards shorter wavelengths for these transitions with heavier metal (e.g. Table 4: $\mathrm{Al} \rightarrow \mathrm{Ga} \rightarrow \mathrm{In}=329.5 \mathrm{~nm} \rightarrow 327.3 \mathrm{~nm} \rightarrow 325.2 \mathrm{~nm}$ ), most likely due to the concomitant elongation of the $\mathrm{M}-\mathrm{O}$ bonds, resulting in a small increase in the dimensions of the complexes with retained general shape. Overall, however, the barycenters of the three calculated lowest-energy transitions for $\left[\mathrm{M}(\mathbf{1})_{3}\right]$ stay in a rather narrow range $\left(\lambda_{\max } \approx 325-329 \mathrm{~nm}\right)$.

Table 4. TD-DFT calculations: Vertical singlet-singlet excitation energies, wavelengths, oscillator strengths, and composition of the excited-state functions of the fac isomers of $\left[\mathrm{M}(\mathbf{1})_{3}\right]$.

\begin{tabular}{|c|c|c|c|c|c|}
\hline \multicolumn{2}{|c|}{$f a c-\left[\mathrm{Al}(\mathbf{1})_{3}\right]^{\mathrm{a}}$} & \multicolumn{2}{|c|}{$f a c-\left[\mathrm{Ga}(\mathbf{1})_{3}\right]^{\mathrm{a}}$} & \multicolumn{2}{|c|}{$f a c-\left[\operatorname{In}(\mathbf{1})_{3}\right]^{b}$} \\
\hline $\begin{array}{c}\lambda_{\text {abs }}[\mathrm{nm}] \\
\text { (osc. strength f) }\end{array}$ & $\begin{array}{c}\text { Transition } \\
\text { (composition) }^{\mathrm{c}}\end{array}$ & $\begin{array}{c}\lambda_{\text {abs }}[\mathrm{nm}] \\
\text { (osc. strength f) }\end{array}$ & $\begin{array}{c}\text { Transition } \\
\text { (composition) }^{\mathrm{d}}\end{array}$ & $\begin{array}{c}\lambda_{\text {abs }}[\mathrm{nm}] \\
\text { (osc. strength f) }\end{array}$ & $\begin{array}{c}\text { Transition } \\
{\text { (composition })^{\mathrm{d}}}^{\text {(comoli }}\end{array}$ \\
\hline $329.5(0.1031)$ & $\begin{array}{l}174 \rightarrow 177(-0.12552) \\
176 \rightarrow 178(-0.62810)\end{array}$ & $327.3(0.1146)$ & $\begin{aligned} 183 & \rightarrow 186(-0.17407) \\
183 & \rightarrow 188(-0.11691) \\
184 & \rightarrow 187(-0.12001) \\
185 & \rightarrow 187(0.60085)\end{aligned}$ & $325.2(0.1152)$ & $\begin{aligned} 161 & \rightarrow 175(-0.11068) \\
162 & \rightarrow 174(0.10089) \\
162 & \rightarrow 177(-0.11013) \\
169 & \rightarrow 174(-0.14515) \\
170 & \rightarrow 172(-0.18630) \\
170 & \rightarrow 173(-0.15426) \\
171 & \rightarrow 174(0.54353) \\
171 & \rightarrow 177(0.10679)\end{aligned}$ \\
\hline $329.5(0.1031)$ & $\begin{array}{l}175 \rightarrow 177(0.12395) \\
176 \rightarrow 179(0.62812)\end{array}$ & $327.3(0.1147)$ & $\begin{aligned} 183 & \rightarrow 187(-0.12027) \\
184 & \rightarrow 186(-0.17005) \\
184 & \rightarrow 188(0.12246) \\
185 & \rightarrow 188(0.60071)\end{aligned}$ & $325.2(0.1168)$ & $\begin{aligned} 160 & \rightarrow 176(0.12994) \\
161 & \rightarrow 177(0.13054) \\
162 & \rightarrow 175(0.12945) \\
169 & \rightarrow 173(-0.14420) \\
170 & \rightarrow 174(-0.14579) \\
171 & \rightarrow 172(0.57712) \\
171 & \rightarrow 175(-0.10630)\end{aligned}$ \\
\hline $327.8(0.0531)$ & $176 \rightarrow 177(0.65397)$ & $325.3(0.0652)$ & $\begin{aligned} 176 & \rightarrow 189(0.10439) \\
183 & \rightarrow 187(-0.10655) \\
184 & \rightarrow 188(-0.10742) \\
185 & \rightarrow 186(0.63521)\end{aligned}$ & $323.2(0.0145)$ & $\begin{aligned} 169 & \rightarrow 172(-0.18781) \\
169 & \rightarrow 173(0.12782) \\
170 & \rightarrow 174(-0.13201) \\
171 & \rightarrow 173(-0.31337) \\
171 & \rightarrow 176(0.47779) \\
171 & \rightarrow 177(0.19494)\end{aligned}$ \\
\hline $323.7(0.0275)$ & $176 \rightarrow 180(0.65393)$ & $315.4(0.0370)$ & $\begin{array}{l}183 \rightarrow 186(0.42531) \\
183 \rightarrow 188(0.27625) \\
184 \rightarrow 187(0.28439) \\
185 \rightarrow 187(0.32606)\end{array}$ & $314.8(0.0145)$ & $\begin{aligned} 169 & \rightarrow 174(-0.13638) \\
170 & \rightarrow 172(-0.17744) \\
170 & \rightarrow 173(-0.14638) \\
171 & \rightarrow 174(-0.31805) \\
171 & \rightarrow 176(-0.20036) \\
171 & \rightarrow 177(0.48457)\end{aligned}$ \\
\hline
\end{tabular}

${ }^{\mathrm{a}} \mathrm{B} 3 \mathrm{LYP} / 6-31 \mathrm{G}(\mathrm{d}) ;{ }^{\mathrm{b}} \mathrm{B} 3 \mathrm{LYP} / \mathrm{LANL} 2 \mathrm{DZ} ;{ }^{\mathrm{c}}$ Orbital numbers according to Figure $8 ;{ }^{\mathrm{d}}$ For orbital numbers see the Supporting Information. 
Table 5. TD-DFT calculations: Vertical singlet-singlet excitation energies, wavelengths, oscillator strengths, and composition of the excited-state functions of the mer isomers of $\left[\mathrm{M}(\mathbf{1})_{3}\right]$.

\begin{tabular}{|c|c|c|c|c|c|}
\hline \multicolumn{2}{|c|}{$\operatorname{mer}-\left[\operatorname{Al}(\mathbf{1})_{3}\right]^{\mathrm{a}}$} & \multicolumn{2}{|c|}{$m e r-\left[\mathrm{Ga}(\mathbf{1})_{3}\right]^{\mathrm{a}}$} & \multicolumn{2}{|c|}{$\operatorname{mer}-\left[\operatorname{In}(\mathbf{1})_{3}\right]^{\mathrm{b}}$} \\
\hline $\begin{array}{c}\lambda_{\text {abs }}[\mathrm{nm}] \\
\text { (osc. strength f) }\end{array}$ & $\begin{array}{c}\text { Transition } \\
\text { (composition) }^{\mathrm{c}}\end{array}$ & $\begin{array}{c}\lambda_{\text {abs }}[\mathrm{nm}] \\
\text { (osc. strength } \mathrm{f} \text { ) }\end{array}$ & $\begin{array}{c}\text { Transition } \\
{\text { (composition })^{\mathrm{d}}}^{\text {din }}\end{array}$ & $\begin{array}{c}\lambda_{\text {abs }}[\mathrm{nm}] \\
\text { (osc. strength f) }\end{array}$ & $\begin{array}{c}\text { Transition } \\
{\text { (composition })^{\mathrm{d}}}^{\mathrm{d}}\end{array}$ \\
\hline $331.0(0.1041)$ & $\begin{aligned} 174 & \rightarrow 177(0.14188) \\
175 & \rightarrow 177(-0.10348) \\
176 & \rightarrow 177(0.61919) \\
176 & \rightarrow 178(0.13942)\end{aligned}$ & $328.6(0.1137)$ & $\begin{aligned} 174 & \rightarrow 189(-0.11119) \\
183 & \rightarrow 186(0.19920) \\
184 & \rightarrow 186(-0.12835) \\
185 & \rightarrow 186(0.59315) \\
185 & \rightarrow 187(0.12030)\end{aligned}$ & $325.8(0.1277)$ & $\begin{aligned} 160 & \rightarrow 172(0.11326) \\
160 & \rightarrow 175(-0.15465) \\
169 & \rightarrow 172(0.25032) \\
169 & \rightarrow 175(0.10431) \\
170 & \rightarrow 172(-0.14634) \\
171 & \rightarrow 172(0.52206) \\
171 & \rightarrow 174(-0.14314) \\
171 & \rightarrow 175(0.10688)\end{aligned}$ \\
\hline $329.1(0.0703)$ & $\begin{aligned} 167 & \rightarrow 181(0.10023) \\
175 & \rightarrow 178(-0.16726) \\
176 & \rightarrow 177(-0.10648) \\
176 & \rightarrow 178(0.57137) \\
176 & \rightarrow 179(0.23558)\end{aligned}$ & $326.9(0.0883)$ & $\begin{aligned} 176 & \rightarrow 187(-0.10475) \\
176 & \rightarrow 190(0.12359) \\
184 & \rightarrow 187(-0.23953) \\
185 & \rightarrow 187(0.52726) \\
185 & \rightarrow 188(0.25173)\end{aligned}$ & $324.5(0.1085)$ & $\begin{aligned} 160 & \rightarrow 176(0.10514) \\
161 & \rightarrow 173(-0.10227) \\
161 & \rightarrow 176(0.10921) \\
162 & \rightarrow 173(0.10127) \\
162 & \rightarrow 176(-0.12034) \\
169 & \rightarrow 173(-0.13456) \\
170 & \rightarrow 173(-0.25251) \\
171 & \rightarrow 173(0.50415) \\
171 & \rightarrow 174(0.17947) \\
171 & \rightarrow 176(0.13466)\end{aligned}$ \\
\hline $327.2(0.0837)$ & $\begin{aligned} 166 & \rightarrow 179(0.11602) \\
166 & \rightarrow 182(-0.15475) \\
175 & \rightarrow 179(0.14543) \\
176 & \rightarrow 177(0.14488) \\
176 & \rightarrow 178(-0.22224) \\
176 & \rightarrow 179(0.57517)\end{aligned}$ & $325.0(0.0910)$ & $\begin{aligned} 175 & \rightarrow 188(0.12458) \\
175 & \rightarrow 191(-0.16679) \\
184 & \rightarrow 188(0.18582) \\
185 & \rightarrow 186(0.17157) \\
185 & \rightarrow 187(-0.23792) \\
185 & \rightarrow 188(0.53431)\end{aligned}$ & $323.5(0.1047)$ & $\begin{aligned} 161 & \rightarrow 174(0.11735) \\
161 & \rightarrow 177(-0.13872) \\
162 & \rightarrow 174(0.11133) \\
162 & \rightarrow 177(-0.14141) \\
170 & \rightarrow 174(0.22441) \\
171 & \rightarrow 172(0.18608) \\
171 & \rightarrow 173(-0.14979) \\
171 & \rightarrow 174(0.49829) \\
171 & \rightarrow 177(0.14748)\end{aligned}$ \\
\hline $324.1(0.0289)$ & $\begin{aligned} 174 & \rightarrow 177(0.13016) \\
175 & \rightarrow 177(-0.26134) \\
176 & \rightarrow 177(-0.14131) \\
176 & \rightarrow 178(0.57694)\end{aligned}$ & $318.5(0.0383)$ & $\begin{aligned} 183 & \rightarrow 186(-0.33864) \\
184 & \rightarrow 186(0.43876) \\
185 & \rightarrow 186(0.28313) \\
185 & \rightarrow 189(-0.23816)\end{aligned}$ & $317.6(0.0122)$ & $\begin{aligned} 170 & \rightarrow 172(-0.11475) \\
171 & \rightarrow 172(-0.22406) \\
171 & \rightarrow 175(0.62417)\end{aligned}$ \\
\hline
\end{tabular}

${ }_{\mathrm{a}}^{\mathrm{a}} \mathrm{B} 3 \mathrm{LYP} / 6-31 \mathrm{G}(\mathrm{d}) ;{ }^{\mathrm{b}} \mathrm{B} 3 \mathrm{LYP} / \mathrm{LANL} 2 \mathrm{DZ} ;{ }^{\mathrm{c}}$ Orbital numbers according to Figure 8; ${ }^{\mathrm{d}}$ For orbital numbers see the Supporting Information.

Taken together, the theoretical calculations give a clear picture of metal complexes with only small energy differences between $f a c$ and mer isomers and electronic transitions that are almost exclusively located on the ligands without participation of the metal centers. This predicted behavior is consistent with the crystallization behavior, the observed NMR spectra (see section 2.3 above), the assignment of the measured transitions as intra-ligand processes, and the independence of the absorption and emission wavelengths from the nature of the central metal used. 


\section{Conclusion}

In conclusion, group 13 metal complexes with 1,2-HOIQO ligands show bright blue-violet fluorescence in solution. The quantum yields with the hexadentate $\mathrm{H}_{3} 2$ are higher than those for the corresponding tris(bidentate) species $[\mathrm{M}(\mathbf{1})]$. This is most likely due to the more rigid structure of the tripodal ligand design, which reduces non-radiative deactivation pathways of the exited state. DFT calculations are in good agreement with the observed trends in $\left[\mathrm{M}(\mathbf{1})_{3}\right]$. The excellent photophysical properties of these species make them very good candidates for fluorescence applications such as trace analysis of group 13 metals.

\section{Experimental Section}

\subsection{General}

Chemicals were purchased from commercial suppliers and used as received unless stated otherwise. Solvents were dried by standard procedures (benzene: Na-wire, $\mathrm{MeOH}: \mathrm{Mg} / \mathrm{I}_{2}$ ). Pyridine was distilled before use. Elemental analyses and mass spectrometry were performed by the microanalytical and mass spectrometry facilities of the University of California, Berkeley. NMR spectra were measured on Bruker AVQ-400 $\left({ }^{1} \mathrm{H}: 400 \mathrm{MHz},{ }^{13} \mathrm{C}: 101 \mathrm{MHz}\right)$ and DRX-500 $\left({ }^{1} \mathrm{H}: 500 \mathrm{MHz}\right)$.

\subsection{Synthesis of Ligand H1}

\section{Benzyl protected ligand H1}

Benzyl-protected 1,2-HOIQO 3-carboxylic acid chloride ${ }^{8 \mathrm{a}}$ (4.57 g, $14.6 \mathrm{mmol}, 1.0$ equiv.) was dissolved in dry $\mathrm{CH}_{2} \mathrm{Cl}_{2}(100 \mathrm{~mL})$ and added dropwise to an ice-cooled mixture of $\mathrm{MeOH}(50 \mathrm{~mL})$ and $\mathrm{MeNH}_{2}\left(30 \mathrm{~mL}, 40 \%\right.$ in $\left.\mathrm{H}_{2} \mathrm{O}\right)$. After complete addition, the ice-bath was removed and the reaction was stirred for $12 \mathrm{~h}$ at ambient temperature. Sat. aq. $\mathrm{NaHCO}_{3}(100 \mathrm{~mL})$ was added and the organic phase was separated. The water layer was extracted with additional $\mathrm{CH}_{2} \mathrm{Cl}_{2}(3 \times 50 \mathrm{~mL})$, the combined organic phases were dried $\left(\mathrm{MgSO}_{4}\right)$, and concentrated under reduced pressure. The pale-yellow solid was recrystallized from $\mathrm{MeOH}$ to yield a colorless solid (3.72 g, 83\%). 
Mp 155-157 ${ }^{\circ}$. ${ }^{1} \mathrm{H}-\mathrm{NMR}\left(400 \mathrm{MHz}, \mathrm{CDCl}_{3}\right): \delta=8.30(\mathrm{~d}, J=7.9 \mathrm{~Hz}, 1 \mathrm{H}), 7.61-7.55(\mathrm{~m}, 1 \mathrm{H}), 7.51-$

$7.41(\mathrm{~m}, 4 \mathrm{H}), 7.38-7.31(\mathrm{~m}, 3 \mathrm{H}), 7.28-7.20(\mathrm{~m}, 1 \mathrm{H}), 6.84(\mathrm{~s}, 1 \mathrm{H}), 5.27(\mathrm{~s}, 2 \mathrm{H}), 2.86(\mathrm{~d}, J=4.9 \mathrm{~Hz}, 3$

H) ppm. ${ }^{13} \mathrm{C}-\mathrm{NMR}\left(101 \mathrm{MHz}, \mathrm{CDCl}_{3}\right): \delta=161.3,158.6,136.0,134.5,133.3,132.7,130.1,129.3$, 128.6, 128.0, 127.4, 127.2, 127.1, 108.1, 79.1, 26.7 ppm. MS $(\mathrm{FAB}+): \mathrm{m} / \mathrm{z}(\%)=309\left(100,\left[\mathrm{M}+\mathrm{H}^{+}\right]^{+}\right)$. Anal. Calcd. for $\mathrm{C}_{18} \mathrm{H}_{16} \mathrm{~N}_{2} \mathrm{O}_{3}\left(M_{\mathrm{r}}=308.33\right)$ : C, 70.12; H, 5.23; N, 9.09. Found: C, 70.09; H, 5.14; N, 9.09 .

\section{Ligand H1}

The benzyl-proteced ligand H1 (0.56 g, $1.8 \mathrm{mmol}, 1.0$ equiv.) was dissolved in a mixture of glacial HOAc $(10 \mathrm{~mL})$ and conc. $\mathrm{HCl}(10 \mathrm{~mL})$ and heated to $50^{\circ} \mathrm{C}$ (bath temperature) for $48 \mathrm{~h}$. The colorless solution was concentrated under reduced pressure (bath temperature $<40^{\circ} \mathrm{C}$ ) and the residual crude product was dried in vacuo for additional $8 \mathrm{~h}$. The product $\mathrm{H} 1$ was obtained as a colorless solid $(0.39 \mathrm{~g}$, quant.).

Mp 207-211 ${ }^{\circ} \mathrm{C} .{ }^{1} \mathrm{H}-\mathrm{NMR}\left(400 \mathrm{MHz}, \mathrm{DMSO}_{\mathrm{d}}\right): \delta=8.63(\mathrm{q}, J=4.7 \mathrm{~Hz}, 1 \mathrm{H}), 8.20(\mathrm{~d}, J=8.0 \mathrm{~Hz}, 1$ H), 7.75-7.67 (m, $2 \mathrm{H}), 7.57-7.50(\mathrm{~m}, 1 \mathrm{H}), 6.75(\mathrm{~s}, 1 \mathrm{H}), 2.74(\mathrm{~d}, J=4.7 \mathrm{~Hz}, 3 \mathrm{H}) \mathrm{ppm} .{ }^{13} \mathrm{C}-\mathrm{NMR}(101$ MHz, DMSO-d $\left.{ }_{6}\right): \delta=161.8,158.1,138.6,135.1,132.7,127.7,127.3,127.1,126.1,103.9,26.4$ ppm. MS $(\mathrm{FAB}+): \mathrm{m} / \mathrm{z}(\%)=219\left(100,\left[\mathrm{M}+\mathrm{H}^{+}\right]^{+}\right)$. Anal. Calcd. for $\mathrm{C}_{11} \mathrm{H}_{10} \mathrm{~N}_{2} \mathrm{O}_{3}\left(M_{\mathrm{r}}=218.21\right): \mathrm{C}, 60.55 ; \mathrm{H}$, 4.62; N, 12.84. Found: C, 60.12; H, 4.72; N, 12.58.

\subsection{Syntheses of the Metal Complexes}

\section{$\left[\mathrm{Al}(1)_{3}\right] \bullet 2 \mathrm{H}_{2} \mathrm{O}$}

Ligand $\mathrm{H1}$ (83 mg, $380 \mu \mathrm{mol}, 3.0$ equivs.) was dissolved in $\mathrm{MeOH}(4 \mathrm{~mL})$. A solution of $\mathrm{Al}(\mathrm{acac})_{3}$ (41 mg, $127 \mu \mathrm{mol}, 1.0$ equiv.) in $\mathrm{MeOH}(4 \mathrm{~mL})$ was added, followed by pyridine (300 mg). The colorless mixture was heated to reflux for $2 \mathrm{~h}$. After cooling to ambient temperature and standing for 5 $\mathrm{h}$, the colorless solid was collected, washed with $\mathrm{MeOH}$, and dried in vacuo at $40^{\circ} \mathrm{C}$ (bath temperature) for $15 \mathrm{~h}$. The complex was obtained as slightly pink solid (35 mg, 39\%). 
Mp 214-220 ${ }^{\circ}$. ${ }^{1} \mathrm{H}-\mathrm{NMR}\left(400 \mathrm{MHz}, \mathrm{CDCl}_{3}\right): \delta=9.88-9.59(\mathrm{~m}, 3 \mathrm{H}), 8.51-8.34(\mathrm{~m}, 3 \mathrm{H}), 8.25-8.07$

$(\mathrm{m}, 3 \mathrm{H}), 7.96-7.56(\mathrm{~m}, 9 \mathrm{H}), 3.09-2.89(\mathrm{~m}, 9 \mathrm{H}) \mathrm{ppm} .{ }^{13} \mathrm{C}-\mathrm{NMR}\left(101 \mathrm{MHz}, \mathrm{CDCl}_{3}\right): \delta=160.2,158.0$, $133.4,133.3,132.3,132.17,131.1,129.10,129.07,128.90,128.86,128.13,128.08,128.03,126.3$, $126.2,126.11,126.06,121.68,121.54,115.46,115.44,115.30,115.27,115.20,26.85,26.83,26.76$ ppm. MS $(\mathrm{FAB}+): \mathrm{m} / \mathrm{z}(\%)=1139\left(20,\left[\mathrm{Al}_{2} \mathrm{~L}_{5}\right]^{+}\right), 679\left(37,\left[\mathrm{M}+\mathrm{H}^{+}\right]^{+}\right), 461\left(100,\left[\mathrm{M}^{-} \mathrm{L}^{-}\right]^{+}\right)$. Anal. Calcd. for $\mathrm{C}_{33} \mathrm{H}_{27} \mathrm{AlN}_{6} \mathrm{O}_{9} \bullet 2 \mathrm{H}_{2} \mathrm{O}\left(M_{\mathrm{r}}=714.61\right)$ : C, 55.46; H, 4.37; N, 11.76. Found: C, 55.66; H, 3.98; N, 11.69.

\section{$\left[\mathrm{Ga}(1)_{3}\right] \bullet 1.5 \mathrm{H}_{2} \mathrm{O}$}

Ligand $\mathrm{H1}(86.0 \mathrm{mg}, 394 \mu \mathrm{mol})$ was dissolved in $\mathrm{MeOH}(4 \mathrm{~mL})$. A solution of $\mathrm{Ga}\left(\mathrm{NO}_{3}\right)_{3} \bullet \mathrm{x} \mathrm{H}_{2} \mathrm{O}$ (48.5 mg) in $\mathrm{MeOH}$ (4 mL) was added, followed by pyridine (330 mg). The colorless mixture was heated to reflux for $2 \mathrm{~h}$. After cooling to ambient temperature, the colorless solid was collected, washed with $\mathrm{MeOH}$, and dried in vacuo at $40^{\circ} \mathrm{C}$ (bath temperature) for $15 \mathrm{~h}$. The complex was obtained as slightly pink solid (72 mg, 73\%).

Mp 217-222 ${ }^{\circ} \mathrm{C} .{ }^{1} \mathrm{H}-\mathrm{NMR}\left(400 \mathrm{MHz}, \mathrm{CDCl}_{3}\right): \delta=9.74-9.60(\mathrm{br}, 3 \mathrm{H}), 8.44(\mathrm{~d}, J=8.2 \mathrm{~Hz}, 3 \mathrm{H}), 8.19$ $(\mathrm{s}, 3 \mathrm{H}), 7.87(\mathrm{~d}, J=9.0 \mathrm{~Hz}, 3 \mathrm{H}), 7.79-7.73(\mathrm{~m}, 3 \mathrm{H}), 7.69-7.63(\mathrm{~m}, 3 \mathrm{H}), 2.98(\mathrm{~d}, J=4.9 \mathrm{~Hz}, 9 \mathrm{H})$ ppm. ${ }^{13} \mathrm{C}-\mathrm{NMR}\left(101 \mathrm{MHz}, \mathrm{CDCl}_{3}\right): \delta=160.4,157.7,132.9,132.2,131.5,129.1,128.1,126.4,121.9$,

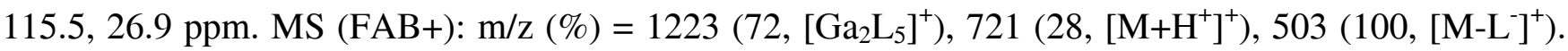
Anal. Calcd. for $\mathrm{C}_{33} \mathrm{H}_{27} \mathrm{GaN}_{6} \mathrm{O}_{9} \bullet 1.5 \mathrm{H}_{2} \mathrm{O}\left(M_{\mathrm{r}}=\right.$ 748.35): C, 52.96; H, 4.04; N, 11.23. Found: C, 53.30; $\mathrm{H}, 4.00 ; \mathrm{N}, 11.25$.

\section{$\left[\operatorname{In}(1)_{3}\right] \bullet 1.5 \mathrm{H}_{2} \mathrm{O}$}

Ligand H1 (51.0 mg, $234 \mu \mathrm{mol}, 3.0$ equivs.) was dissolved in $\mathrm{MeOH}(4 \mathrm{~mL})$. A solution of $\operatorname{In}(\mathrm{OAc})_{3}$ - $\mathrm{x} \mathrm{H}_{2} \mathrm{O}$ (28\% In, $32.0 \mathrm{mg}, 1.0$ equiv.) in $\mathrm{MeOH}$ (4 mL) was added, followed by pyridine (300 mg). The colorless mixture was heated to reflux for $2 \mathrm{~h}$. After cooling to ambient temperature, the colorless solid was collected, washed with $\mathrm{MeOH}$, and dried in vacuo at $40^{\circ} \mathrm{C}$ (bath temperature) for $15 \mathrm{~h}$. The complex was obtained as slightly pink solid (52 mg, 84\%). 
Mp 249-254 ${ }^{\circ}$. ${ }^{1} \mathrm{H}-\mathrm{NMR}\left(400 \mathrm{MHz}, \mathrm{CDCl}_{3}\right): \delta=9.74$ (br s, $\left.3 \mathrm{H}\right), 8.43(\mathrm{~d}, J=8.1 \mathrm{~Hz}, 3 \mathrm{H}), 8.11(\mathrm{~s}$, $3 \mathrm{H}), 7.79(\mathrm{~d}, J=8.1 \mathrm{~Hz}, 3 \mathrm{H}), 7.70(\mathrm{t}, J=7.3 \mathrm{~Hz}, 3 \mathrm{H}), 7.70(\mathrm{t}, J=7.7 \mathrm{~Hz}, 3 \mathrm{H}), 2.99(\mathrm{~d}, J=4.8 \mathrm{~Hz}, 9$

H) ppm. ${ }^{13} \mathrm{C}-\mathrm{NMR}\left(101 \mathrm{MHz}, \mathrm{CDCl}_{3}\right): \delta=160.7,158.4,132.6,132.3,132.1,129.0,128.0,126.3$, 123.0, 115.3, 26.9 ppm. MS (FAB+): m/z $(\%)=767\left(100,\left[\mathrm{M}+\mathrm{H}^{+}\right]^{+}\right), 549\left(70,\left[\mathrm{M}^{-} \mathrm{L}^{-}\right]^{+}\right)$. Anal. Calcd. for $\mathrm{C}_{33} \mathrm{H}_{27} \mathrm{InN}_{6} \mathrm{O}_{9} \bullet 1.5 \mathrm{H}_{2} \mathrm{O}\left(M_{\mathrm{r}}=793.44\right)$ : C, 49.95; H, 3.81; N, 10.59. Found: C, 50.35; H, 3.75; N, 10.56 .

\section{$[\mathrm{Ga}(2)] \bullet 1.5 \mathrm{H}_{2} \mathrm{O}$}

A solution of ligand $\mathrm{H}_{3} 2 \bullet \mathrm{HCl} \bullet 2 \mathrm{H}_{2} \mathrm{O} \bullet \mathrm{MeOH}(133 \mathrm{mg}, 164 \mu \mathrm{mol}, 1.0$ equiv.) in $\mathrm{MeOH}(5 \mathrm{~mL})$ was treated with solid $\mathrm{Ga}(\mathrm{acac})_{3}(60 \mathrm{mg}, 164 \mu \mathrm{mol}, 1.0$ equiv.), pyridine (480 $\mathrm{mg}$ ) and heated to reflux for $1 \mathrm{~h}$. The resulting fine suspension was cooled to ambient temperature, the precipitate collected on a filter, and washed with $\mathrm{MeOH}$. After drying in vacuo at $50{ }^{\circ} \mathrm{C}$ (bath temp.) for $9 \mathrm{~h}$, the gallium complex (110 mg, 84\%) was obtained as a colorless solid.

M.p. $>300^{\circ} \mathrm{C} .{ }^{1} \mathrm{H}-\mathrm{NMR}\left(400 \mathrm{MHz}, \mathrm{CDCl}_{3}\right): \delta=10.36-10.30(\mathrm{~m}, 3 \mathrm{H}), 8.56(\mathrm{~d}, J=8.2 \mathrm{~Hz}, 3 \mathrm{H}), 8.09$ (s, $3 \mathrm{H}), 7.86(\mathrm{~d}, J=8.2 \mathrm{~Hz}, 3 \mathrm{H}), 7.79-7.66(\mathrm{~m}, 6 \mathrm{H}), 3.74$ (br s, $6 \mathrm{H}), 2.66$ (br s, $6 \mathrm{H}) \mathrm{ppm} .{ }^{13} \mathrm{C}-\mathrm{NMR}$ $\left(101 \mathrm{MHz} \mathrm{CDCl}_{3}\right): \delta=159.7,152.8,133.0,132.1,131.5,129.1,128.1,126.3,122.0,115.3,53.8,35.7$ ppm. MS $(\mathrm{FAB}+): \mathrm{m} / \mathrm{z}(\%)=774\left(100,[\mathrm{M}+\mathrm{H}]^{+}\right)$. Anal. Calcd. for $\mathrm{C}_{36} \mathrm{H}_{30} \mathrm{GaN}_{7} \mathrm{O}_{9} \bullet 1.5 \mathrm{H}_{2} \mathrm{O}\left(M_{\mathrm{r}}=\right.$ 801.42): C, 53.95; H, 4.15; N, 12.23. Found: C, 54.11; H, 3.89; N, 11.74.

$[\operatorname{In}(2)]$

A solution of ligand $\mathrm{H}_{3} 2 \bullet \mathrm{HCl} \bullet 2 \mathrm{H}_{2} \mathrm{O} \bullet \mathrm{MeOH}(145 \mathrm{mg}, 179 \mu \mathrm{mol}, 1.0$ equiv.) in $\mathrm{MeOH}(6 \mathrm{~mL})$ was treated with solid $\mathrm{In}(\mathrm{OAc})_{3} \bullet \mathrm{x} \mathrm{H}_{2} \mathrm{O}$ (28\% In, $73 \mathrm{mg}, 179 \mu \mathrm{mol}, 1.0$ equiv.), pyridine $(520 \mathrm{mg})$ and heated to reflux for $1 \mathrm{~h}$. The resulting suspension was cooled to ambient temperature, the precipitate collected on a filter, and washed with $\mathrm{MeOH}$. After drying in vacuo at $50{ }^{\circ} \mathrm{C}$ (bath temp.) for $9 \mathrm{~h}$, the In complex (80 mg, 54\%) was obtained as a pale-yellow solid. Single crystals were grown by slow diffusion of diethyl ether into a solution of $[\operatorname{In}(2)]$ in $\mathrm{CHCl}_{3}$. 
M.p. $>300^{\circ} \mathrm{C} .{ }^{1} \mathrm{H}-\mathrm{NMR}\left(400 \mathrm{MHz}, \mathrm{CDCl}_{3}\right): \delta=10.61-10.51(\mathrm{~m}, 3 \mathrm{H}), 8.56(\mathrm{~d}, J=8.1 \mathrm{~Hz}, 3 \mathrm{H}), 8.14$

(s, $3 \mathrm{H}), 7.85(\mathrm{~d}, J=7.6 \mathrm{~Hz}, 3 \mathrm{H}), 7.78-7.66(\mathrm{~m}, 6 \mathrm{H}), 3.84-3.75(\mathrm{~m}, 6 \mathrm{H}), 2.78-2.70(\mathrm{~m}, 6 \mathrm{H}), 1.58$ (s, 6

H) ppm. ${ }^{13} \mathrm{C}-\mathrm{NMR}\left(101 \mathrm{MHz}, \mathrm{CDCl}_{3}\right): \delta=160.1,158.2,132.6,132.2,131.9,129.1,128.1,126.2$, 122.9, 115.6, 53.2, 36.0 ppm. MS (FAB+): m/z $(\%)=820\left(100,[\mathrm{M}+\mathrm{H}]^{+}\right), 781\left(58,[\mathrm{M}+\mathrm{H}]^{+}\right), 613(79$, $\left.[\mathrm{M}+\mathrm{H}]^{+}\right)$. Anal. Calcd. for $\mathrm{C}_{36} \mathrm{H}_{30} \mathrm{InN}_{7} \mathrm{O}_{9}\left(M_{\mathrm{r}}=819.48\right)$ : C, 52.76; H, 3.69; N, 11.96. Found: C, 52.47; H, 3.59; N, 11.68 .

\subsection{Single-Crystal X-Ray Analysis:}

A fragment of a yellow plate-like crystal of the title compound having approximate dimensions of 0.37 × $0.22 \times 0.07 \mathrm{~mm}^{3}$ was mounted on a Kapton loop using Paratone $\mathrm{N}$ hydrocarbon oil. All measurements were made on a Siemens SMART $\mathrm{CCD}^{20}$ area detector with graphite monochromated Mo-K radiation. Cell constants and an orientation matrix, obtained from a least-squares refinement using the measured positions of 1901 centered reflections with $\mathrm{I}>10$ (I) in the range $3.59<<21.94^{\circ}$ corresponded to a rhombohedral cell (hexagonal setting). The data were collected at a temperature of 169(2) K. Frames corresponding to an arbitrary hemisphere of data were collected using scans of $0.3^{\circ}$ counted for a total of 10 seconds per frame. Data were integrated by the program $\mathrm{SAINT}^{21}$ to a maximum value of $26.40^{\circ}$. The data were corrected for Lorentz and polarization effects. Data were analyzed for agreement and possible absorption using XPREP. ${ }^{22}$ An empirical absorption correction based on comparison of redundant and equivalent reflections was applied using $\mathrm{SADABS}^{23}\left(\mathrm{~T}_{\max }=\right.$ $\left.0.95, \mathrm{~T}_{\min }=0.81\right)$. Of the 7861 reflections that were collected, 2116 were unique; equivalent reflections were merged. No decay correction was applied. The structure was solved within the WinGX ${ }^{24}$ package by direct methods $\left(\right.$ SIR92 ${ }^{25}$ ) and expanded using Fourier techniques (SHELXL-97 ${ }^{26}$ ). H atoms were positioned geometrically, with $\mathrm{C}-\mathrm{H}=0.93 \AA$ for $\mathrm{C}_{\text {arom }}-\mathrm{H}$ groups, $\mathrm{C}-\mathrm{H}=0.97 \AA$ for $\mathrm{CH}_{2}$ groups, $\mathrm{N}-\mathrm{H}=$ $0.86 \AA$ and constrained to ride on their parent atoms. $\mathrm{U}_{\text {iso }}(\mathrm{H})$ values were set at 1.2 times $\mathrm{U}_{\text {eq }}(\mathrm{C})$ for all $\mathrm{H}$ atoms. 


\subsection{Spectroscopic Measurements}

UV-Visible absorption spectra were recorded on a Varian Cary 300 double beam absorption spectrometer using $1 \mathrm{~cm}$ quartz cells. Emission spectra were acquired on a HORIBA Jobin Yvon IBH FluoroLog-3 spectrofluorimeter, equipped with 3 slit double grating excitation and emission monochromators $(2.1 \mathrm{~nm} / \mathrm{mm}$ dispersion, 1200 grooves $/ \mathrm{mm})$. Spectra were reference corrected for both the excitation light source variation (lamp and grating) and the emission spectral response (detector and grating). Luminescence lifetimes were determined on the same HORIBA Jobin Yvon IBH FluoroLog-3 spectrofluorimeter, adapted for time-correlated single photon counting (TCSPC). For these measurements, a pulsed LED was used as the excitation lightsource, with a peak output at $330 \mathrm{~nm}$ and full width at half maximum (FWHM) of $10 \mathrm{~nm}$ and a pulse duration of ca. 800 ps. Emission was monitored perpendicular to the excitation pulse, with spectral selection achieved by passage through a double grating excitation monochromator $(2.1 \mathrm{~nm} / \mathrm{mm}$ dispersion, 1200 grooves $/ \mathrm{mm})$. A thermoelectrically cooled single photon detection module (HORIBA Jobin Yvon IBH, TBX-04-D) incorporating fast rise time PMT, wide bandwidth preamplifier and picosecond constant fraction discriminator was used as the detector. Signals were acquired using an IBH DataStation Hub photon counting module and data analysis was performed using the commercially available DAS 6 decay analysis software package from HORIBA Jobin Yvon IBH, and the reported $\tau$ values are given with an estimated uncertainty of $\pm 10 \%$.

Quantum yields were determined by the optically dilute method using the equation;

$\Phi_{x} / \Phi_{\mathrm{r}}=\left[A_{\mathrm{r}}\left(\lambda_{\mathrm{r}}\right) / A_{\mathrm{x}}\left(\lambda_{\mathrm{x}}\right)\right] *\left[I_{\mathrm{r}}\left(\lambda_{\mathrm{r}}\right) / I_{\mathrm{x}}\left(\lambda_{\mathrm{x}}\right)\right] *\left[n_{\mathrm{x}}^{2} / n_{\mathrm{r}}^{2}\right] *\left[D_{\mathrm{x}} / D_{\mathrm{r}}\right]$

where $A$ is the absorbance at the excitation wavelength, $I$ is the intensity of the excitation light at the same wavelength, $n$ is the refractive index and $D$ is the integrated luminescence intensity. The subscripts ' $x$ ' and ' $r$ ' refer to the sample and reference respectively. Quinine sulfate in $0.5 \mathrm{M}$ sulfuric acid was used as the reference $\left(\Phi_{\mathrm{r}}=0.546\right)$ and the estimated uncertainties in the reported $\Phi$ values are $\pm 15 \%$. 


\subsection{Computational Methods}

All calculations and the preparation of the graphics were performed using the Gaussian 03 (revision

B.04) package. ${ }^{16}$ Molecular geometries were optimized in vacuum without symmetry restraints using density functional theory (DFT) with the B3LYP hybrid exchange correlation functional and the 6$31 \mathrm{G}(\mathrm{d})$ basis set for $\left[\mathrm{Al}(\mathbf{1})_{3}\right]$ and $\left[\mathrm{Ga}(\mathbf{1})_{3}\right]$ and the LANL2DZ basis set for $\left[\operatorname{In}(\mathbf{1})_{3}\right]$, using effective core potentials (ECP) for indium. Frequency analysis in every case confirmed the presence of a real energy minimum for the structures. Time-dependent density functional theory (TD-DFT) in vacuum using the same functional and basis sets as for the geometry optimizations allowed the computation of excitation energies, oscillator strengths, and excited-state compositions.

\section{Acknowledgment}

The authors thank Michael D. Pluth for assistance with NMR spectra. M.S. thanks the German Research Foundation (DFG) for a research fellowship. This research is supported in part by the Director, Office of Science, Office of Basic Energy Sciences, and the Division of Chemical Sciences, Geosciences, and Biosciences of the U.S. Department of Energy at LBNL under Contract No. DEAC02-05CH11231.

Supporting Information Available. CIF file for [In(2)], complete UV-vis and fluorescence spectra for all metal complexes. MOL2 files of the optimized structures of $\left[\mathrm{M}(\mathbf{1})_{3}\right]$ as well as complete orbital diagrams from DFT calculations. This material is available free of charge via the Internet at http://pubs.acs.org.

\section{References}

1 a) Yokel, R.A.; Ackrill, P.; Burgess, E.; Day, J.P.; Domingo, J.L.; Flaten, T.P.; Savory, J. J. Tox. Environ. Health 1996, 48, 667; b) Nayak, P. Environ. Res. Sect. A 2002, 89, 101. 
2 Lever, S.Z.; Lydon, J.D.; Cutler, C.S.; Jurisson, S.S. in Comprehensive Coordination Chemistry II, Chap. 9.20, McCleverty, J.A.; Meyer, T.J., Eds.; Elsevier: Oxford, U.K., 2004.

3 Banger, K.K.; Hepp, A.F. in Encyclopedia of Inorganic Chemistry, Vol. III, King, B.R., Ed.; Wiley: Chichester, U.K., 2005, pp. 1589.

4 Tang, C.W.; Van Slyke, S.A. Appl. Phys. Lett. 1987, 51, 913.

5 Burrows, P.E.; Sapochak, L.S.; McCarty, D.M.; Forrest, S.R.; Thompson, M.E. Appl. Phys. Lett. 1994, 64, 2718.

6 a) Chen, C.H.; Shi, J. Coord. Chem. Rev. 1998, 171, 161; b) Wang, S. Coord. Chem. Rev. 2001, 215, 79; c) Hamada, Y. IEEE Trans. Electron. Devices 1997, 44, 1208.

7 Katyal, M. Talanta 1968, 15, 95.

8 a) Seitz, M.; Pluth, M.D.; Raymond, K.N. Inorg. Chem. 2007, 46, 351; b) Seitz, M.; Oliver, A.G.; Raymond, K.N. J. Am. Chem. Soc. 2007, 129, 11153; c) Seitz, M.; Raymond, K.N. Eur. J. Org. Chem. 2008, 2697.

9 ORTEP-3 for Windows: Farrugia, L.J. J. Appl. Crystallogr. 1997, 30, 565.

10 a) Abrahams, I.; Choi, N.; Henrick, K.; Joyce, H.; Matthews, R.W.; McPartlin, M.; Brady, F.; Waters, S.L. Polyhedron 1994, 13, 513; b) Hilfiker, K.A.; Brechbiel, M.W.; Rogers, R.D.; Planalp, R.P. Inorg. Chem. 1997, 36, 4600.

11 a) Piper, T.S . J. Am. Chem. Soc. 1961, 83, 3908; b) Fay, R.C.; Piper, T.S. Inorg. Chem. 1964, 3, 348; c) Gordon, J.G., II; Holm, R.H. J. Am. Chem. Soc. 1970, 92, 5319. d) Girgis, A.Y.; Fay, R.C. J. Am. Chem. Soc. 1970, 92, 7061.

12 Selected examples: a) Monga, V.; Patrick, B.O.; Orvig, C. Inorg. Chem. 2005, 44, 2666; b) Hoveyda, H.R.; Karunaratne, V.; Rettig, S.J.; Orvig, C. Inorg. Chem. 1992, 31, 5408; c) Zhang, Z.; Rettig, S.J.; 
Orvig, C. Inorg. Chem. 1991, 30, 509; d) Lutz, T.G.; Clevette, D.J.; Rettig, S.J.; Orvig, C. Inorg. Chem. 1989, 28, 715; e) Matsuba, C.A.; Rettig, S.J.; Orvig, C. Can. J. Chem. 1988, 66, 1809.

13 Cockrell, G.M.; Zhang, G.; VanDerveer, D.G.; Thummel, R.P.; Hancock, R.D. J. Am. Chem. Soc. 2008, 130, 1420 and refs. cited therein.

14 For a complete list of spectra see the Supporting Information.

15 Selected recent examples: a) Wang, J.; Oyler, K.D.; Bernhard, S. Inorg. Chem. 2007, 46, 5700; b) Thoi, V.S.; Stork, J.R.; Madge, D.; Cohen, S.M. Inorg. Chem. 2006, 45, 10688; c) Mulon, J.-B.; Destandau, E.; Alain, V.; Bardez, E. J. Inorg. Biochem. 2005, 99, 1749; d) Launay, F.; Alain, V.; Destandau, E.; Ramos, N.; Bardez, E.; Baret, P.; Pierre, J.-L. New. J. Chem. 2001, 25, 1269.

16 Frisch, M.J.; et al. 2003, Gaussian Inc., Pittsburgh, USA.

17 Selected recent examples: a) Amati, M.; Lelj, F. J. Phys. Chem. 2003, 107, 2560; b) Zhang, J.; Frenking, G. Chem. Phys. Lett. 2004, 394, 120; c) Perez-Bolivar, C.; Montes, V.A.; Anzenbacher, Jr., P. Inorg. Chem. 2006, 45, 9610; d) Lin, B.C.; Cheng, C.P.; Zhi You, Z.-Q.; Hsu, C.-P. J. Am. Chem. Soc. 2005, 127, 66.

18 The necessary change in basis set from 6-31G(d) to LANL2DZ makes it somewhat problematic to compare the calculations for $\mathrm{Al}$ and $\mathrm{Ga}$ on the one hand, and In on the other hand. This could in principle affect the comparability of absolute values for e.g. energies, wavelengths, etc. Two of the main aspects in our context, however, namely the energy difference between $f a c$ and mer isomers and the demonstration of the non-involvement of metal-based orbitals in the lowest-energy transitions are certainly not influenced negatively.

19 For more details see the Supporting Information.

${ }^{20}$ SMART (V5.059): Area-Detector Software Package, Bruker Analytical X-ray Systems, Inc.: Madison, WI, (1995-99). 
21 SAINT (V7.07B): SAX Area-Detector Integration Program; Siemens Industrial Automation, Inc.: Madison, WI, (2005).

${ }^{22}$ XPREP (V6.12): Part of the SHELXTL Crystal Structure Determination Package, Bruker AXS Inc.: Madison, WI, (1995).

23 SADABS (V2.10): Siemens Area Detector Absorption correction program, George Sheldrick, (2005).

24 WinGX 1.70.01: Farrugia, L.J. J. Appl. Crystallogr. 1999, 32, 837-838.

25 SIR92: Altomare, A.; Cascarano, G.; Giacovazzo, C.; Guagliardi, A. J. Appl. Crystallogr. 1993, 26, 343.

26 SHELX97 - Programs for Crystal Structure Analysis (Release 97-2). Sheldrick, G.M., Institut für Anorganische Chemie der Universität, Tammanstrasse 4, D-3400 Göttingen, Germany, 1998. 